\title{
眼窩壁骨折治療に関する二・三の工夫
}

\author{
土師 知行 ${ }^{1)} \cdot$ 平本 道昭 ${ }^{2)} \cdot$ 大八木章博 ${ }^{3)}$
}

\section{Some Devices on Treatment for Orbital Wall Fracture}

\author{
Tomoyuki Haji and Michiaki Hiramoto \\ (Kurashiki Central Hosp.) \\ Shouhaku Ohyagi \\ (Osaka Red Cross Hosp.)
}

With regard to treatment of two cases of orbital wall fracture with fracture of the orbital rim:

(1) A trans-eyelid approach to fractures of the orbital floor is better than the transmaxillary approach, particularly for treatment of orbital rim fracture and/or bone graft to the defect of the orbital floor.

(2) It is not necessary to remove mucosa of maxillary antrum, and an adequate dose of antibiotics should be given, when there has not been severe sinusitis before the trauma.

(3) Pieces of the fractured anterior wall of the antrum are made into a bony plate by tying with nylon thread. contents.

This plate is then placed over the defect of the orbital floor to support the orbital

(4) We place a balloon catheter in the maxillary antrum through a naso-antral window and expand it to support the orbital floor and stop bleeding from the antrum.

$$
\text { はじめに }
$$

眼窩壁骨折, 特に眼窩底の骨折に関しては 1957年 Smith ${ }^{1)}$ が, Blow-out fracture なる語を使 用して以来, 数多くの報告がある. Blow-out fracture は眼窩縁に骨折がなく, 眼窩壁に限局して 骨折が認められる pure type と, 眼窩縁, 眼窩壁のいずれにも骨折が認められる impure type と に分けられている.

最近われわれは後者に属する症例の骨折部の整復に関して, 二・三の工夫を行っているので, 若 干の文献的考察を加えて報告する.

1) 倉敷中央病院耳鼻咽喉科

2) " 形成外科

3 ）大阪赤十字病院耳鼻咽喉科 
症

$<$ 症例 $1>$

患者 : 32歳, 男子.

主訴：左下眼瞼点状出血，陥凹，腫張及び鼻 出血.

病歴：昭和53年 8 月 27 日, ソフトボールの試 合中に打球が左眼窩部を直撃した．同日来院し た.

初診時所見 : 左下眼瞼点状出血，腫張を認め た.ただし, 複視, 眼球運動障害, 眼球偏位, 視力低下はなかった。

レ線所見：左煩骨弓及び眼窩下壁に骨折線お よび偏位が見られ，左上顎洞に混濁像を認めた (図 1 ).

手術：受傷後12日目に，全麻下で観血的整復 術を行った。骨折部へのアプローチは左下眼瞼 縁直下 $2 \sim 3 \mathrm{~mm}$ に横切開を置く下眼瞼経由法で 行った。この方法で手術を進めると, 眼窩下孔 から眼窩底にかけて線状骨折があり，眼窩底に 骨欠損の存在することがわかった。また，この 骨欠損部を介して脂肪組織を主体とする眼窩内 容の上顎洞内への嵌入が認められた，以上の所 見の他に，上顎洞前側壁に骨折と骨欠損があり 眼窩上外方と煩骨弓に線状骨折があることがわ かった。

眼窩上外方および煩骨弓の骨折を22号鋼線で 固定し，眼窩下孔を含む骨折はその内，外方で それぞれ22号鋼線で固定した。 さらに上顎洞内 に嵌入している眼窩内容を充分に眼窩内に用手 還元した．次に，上顎洞内に落ち込んでいる上 顎洞前壁および側壁の一部之思われる板状骨片 を，38号鋼線で接合して一枚の骨板とし，これ を用いて眼窩底の骨欠損部を補った。この際， 骨板の補填は眼窩側から行い，乙れを眼窩縁に 穿った小孔に38号鋼線で固定した．上䪽洞粘膜 は剝離も除去もしなかった。（戍2）

鼻内より下鼻道側壁にスタッケー氏溝状ノミ 及び反対側溝状ノミで対孔を造設し，対孔を介 して14号バルーンカテーテルを上顎洞内に挿入
例

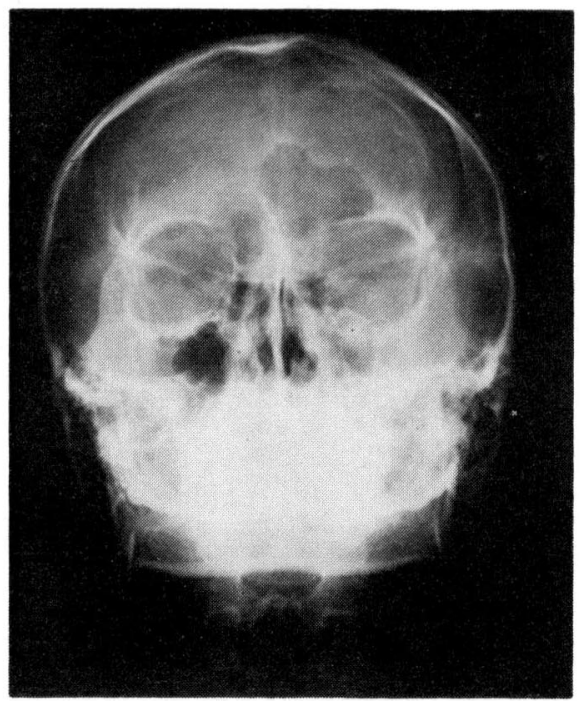

図１ 症例 1 ：左煩骨弓，眼窩下壁に骨折線と偏位が 見られる. 左上顎洞は混濁している.

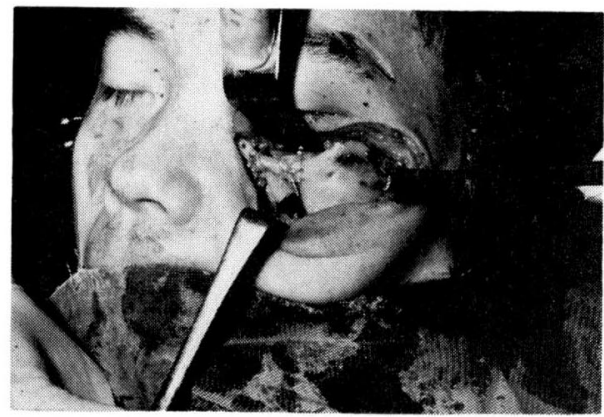

图 2 症例 1 : 眼窩縁の骨折を鋼線で固定した。上顎 洞前壁の骨片を鋼線で接合して一枚の板状骨片 としたものを, 眼窩底の骨欠損部に插置し固定 した.

した. 生理的食塩水 $20 \mathrm{cc}$ をバルーン内に注入 し，眼窩底を下方より支持すると同時に上顎洞 内の止血を図った。

術後10日でバルーンカテーテルを抜去した。 術後 1 力月間は抗生剂を使用した。.以上の操作 で上顎洞内の混濁は減少し（図 3 )，眼科的検 査でも異常所見はみなかった。

$<$ 症例 $2>$

患者 : 25歳，男子. 


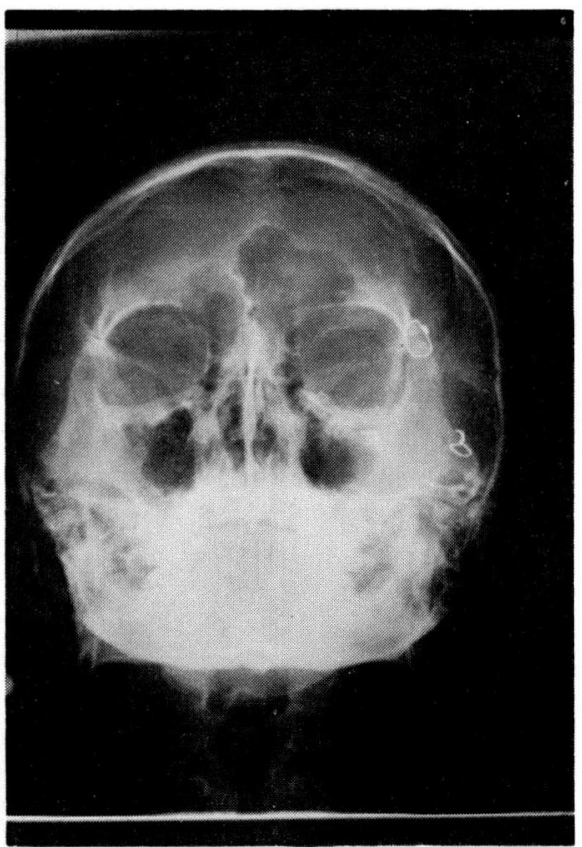

図 3 症例 1 : 術後 1 力月. 接合に用いた鋼線と, 眼 窩底骨欠損部に插置した骨片がわかる．左上顎 洞の混濁は減少している.

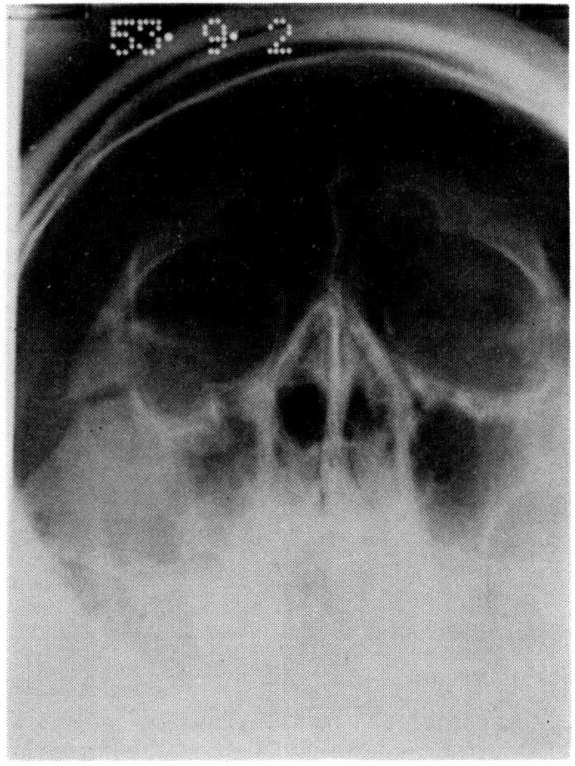

図 4 症例 2 : 眼窩縁の右煩骨弓上縁部と右眼窩下壁 に骨折線が見られる.

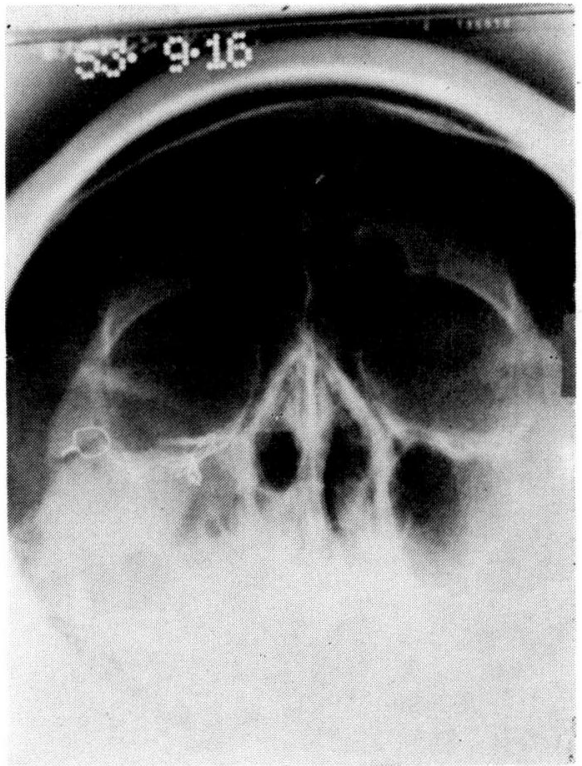

図 5 症例 $2:$ 術後 2 週間. 接合に用いた鋼線と, 眼 窩底に插置した骨片がわかる.

主訴：右眼窩下部圧痛およびしびれ感. 右眼 球結膜下出血.

病歷：昭和 53 年 8 月 30 日, ラクビーの試合中 に他の選手と衝突し，右顔面を側方より打撲し た. 某耳鼻科で右顔面骨折と診断され, 受傷後 4 日目に来院した.

初診時所見：右眼窩下縁陥凹，圧痛およびし びれ感, 右眼球結膜下出血, 開口時右顎関節痛 を認めた. 複視, 眼球運動障害, 眼球偏位, 視 力低下は認められなかった。

レ線所見：右煩骨弓上縁の眼窩縁および右眼 窩下壁に骨折線を認めた。（図 4 ）

手術 : 受傷後 6 日目に, 全麻下で観血的整復 術を行った。骨折部へのアプローチは第 1 例之 同じく下眼瞼経由法で行った。この方法で手術 を進める上(1)眼窩側壁の煩骨弓上縁から深部に およぶもの. (2)眼窩下孔を含み眼窩下壁へおよ ぶもの. (3)眼窩下孔より上顎洞前壁へおよぶも の, の 3 つの骨折が存在するととがわかった. この他に, 眼窩下壁には, 眼窩縁より深部に幅 約 $1 \mathrm{~cm}$, 長さ約 $1.5 \mathrm{~cm}$ の骨欠損があり, 上顎洞 前壁にも骨欠損を認めた．脂肪組織を主とする 
眼窩内容が眼窩底骨欠損部より上顎洞内に嵌入

し，上顎洞内には数個の骨片を認めた.

まず眼窩側壁の骨折部を用手的に整復したの ち鋼線で固定した。次に，上顎洞に嵌入してい る眼窩内容を眼窩内に整復し, 眼窩下壁から上 顎洞前壁にわたる骨折部を鋼線で固定した。眼 窩底骨欠損部に対する補填は次のようにした。 すなわち上顎洞内に落ち込んでいる扁平な骨片 2 個を採取し, ナイロン系で連結して 1 枚の骨 板とした。これを眼窩側より插入し眼窩下壁の

考

眼窩壁骨折の定義，分類はなお混乱している が， Converse ${ }^{2)}$ は表 1 のような分類を試みて いる。すなわち彼は，Blowout fracture を2 型に分類し，眼窩縁に骨折を認めない眼窩壁骨 折を pure blowout fracture と呼び, 眼窩縁 と眼窩壁いずれにも骨折を伴うものを，impure blowout fracture と呼んでいる．前者は， 眼窩に対する前方からの外力で眼窩内圧が高ま り，菲薄な眼窩壁に骨折を起こすため出現する とされ，後者は，眼窩縁が骨折して後方に偏位 するために眼窩壁の骨折がおこると考えられて
骨欠損部に当て，ナイロン系で眼窩縁に固定し た。第 1 例と同じく，下鼻道側壁には対孔を造 設し，ての対孔を介してバルーンカテーテルを 插入し，乙れを生理的食塩水で膨張させ，止血 および眼窩底の支持を図った。 上顎洞粘膜の剝 離，除去は行っていない。（図 5 ）

術後 7 日目にバルーンカテーテルを抜去し た。抗生剂の投与は約 1 力月間続けた。術後 2 週間目の眼科的検査で異常はなかった。

\section{按}

いるわれわれはその成因から考え，“blowout fractre”という名称は, pure type に限 って用いる方が妥当だと考えている.

眼窩壁骨折の受傷原因として，交通外傷や手 挙，肘，ボールなどによる眼窩部の打撲がある が, impure type の場合, pure type に比べて 交通外傷の占める割合が大きいようである ${ }^{32}$. また，最近はスポーツ外傷によるものも増加し ている.

臨床症状としては，眼窩内容の上顎洞への嵌 入による複視, 眼球運動制限, 眼球陥凹, 眼位

表 I Classification of Orbital Fractures

1. Orbiral blowout fractures

A. Pure blowout fractures: fractures through the thin areas of the orbital floor, medial and lateral wall. The orbital rim is intact.

B. Impure blowout fractures: fractures associated with fracture of the adjacent facial bones. The thick orbital rim is fractured, and its backward displacement causes a comminution of the orbital floor; the posterior displacement of the orbital rim permits the traumatizing force to be applied against the orbital contents, which produces a superimposed blowout fracture.

2. Orbital fractures without blowout fracture

A. Linear fractures, in upper maxillary and zygomatic fractures. These fractures are often uncomplicated from the standpoint of the orbit.

B. Comminuted fracture of the orbital floor with prolapse of the orbital contents into the maxillary sinus is often associated with fracture of the midfacial bones.

C. Fracture of the zygoma with frontozygomtic separation and downward displacement of the zygomatic portion of the orbital floor and of the lateral attachment of the suspensory ligament of Lockwood. 
異常, 眼裂狭小や, 眼窩下神経知覚異常あるい は眼窩縁骨折による顔面変形があるが, 受傷後 急性期では, 眼窩周囲の腫張, 皮下出血などで 上記症状がはっきりしないてとがある.

blowout fracture の診断は, 眼窩打撲の既 往, 上記症状の発現, レ線による骨折の証明の 他に traction test の成績が参照される。われ われの経験では, Waters 撮影で眼窩壁の骨 折はよく観察できるが, Fuger I 法, 断層撮 影, あるいは眼窩後前位撮影屯診断上有用であ $ろ^{4) 5)}$. traction test は眼窩底骨折による機械 的な眼球運動制限と, 動眼神経麻瘏などの眼球 運動障害との鑑別に有用性が高い. この検査で は，下直筋眼球付着部をピンセットでつまんで けん引するが，眼筋麻瘏の場合には運動制限は ないけれど, 眼窩底骨折部に眼窩内容が嵌入し ている場合には運動制限を認める. この test は手術の適応を調べたり, 術中の眼窩内容の整 復が完全かどうかを調べたりする場合にも有用 性が高い.

眼球運動制限の他覚的検査としては, RedGreen test (Hess) がすぐれている。術前の眼 球運動制限の程度, 術後の経過の判定には不可 欠と言ってよい，われわれの症例では眼球運動 制限がほとんど見られなかったので，乙のテス 卜は実施しなかった。

手術適忍，手術の時期に関し:ては諸説があ る. Converse $\mathrm{e}^{6)}$ は(1)眼球の他動的な運動制限.

(2)レ線による骨折の証明. (3)眼球陥凹. の 3 項 目をあげ，このうち 1 項目以上陽性所見が得ら れる場合を手術適応としている，また，彼は手 術時期は受傷後数日, 腫張の引くのを待って手 術するのが良いが， 1 週間を越えてはならない と述べている. Emery ${ }^{7)}$ は保存的な処置のみで 複視の消失する例の少なくないことをあげ，受 傷後 2 週間は経過を観察し, 複視の改善を見る あのは手術の必要なしとしている，但し，複視 がなく, traction test で陰性であっても,レ 線で広範な眼窩内容の上顎洞への嵌入が認めら れるものは, 放置すると眼球陷凹, 眼球偏位,
複視のおこる公算が大であるので, 早期に手術 を行うべきであると述べている，Pufferman ${ }^{8)}$ は Blowout fracture 57例のすへてを保存的に 治療し，全例に複視などの症状の軽快を認めた と報告し, 早期手術は必要でなく, 受傷後 4 6 力月間は保存的に観察し, 手術の適否を決め るべきと述べている．以上の諸家の報告の差異 は，それぞれの対象とする症例の違いあ関係し ているものと思われる。 ての問題に対するわれ われの考えは，眼窩縁と眼窩壁に骨折を合併す るものに対しては, 複視, 眼球陷凹, 眼球運動 制限，眼球偏位などの症状がない場合でも手術 が必要で，その時期に関しては整復手術の容易 な受傷後 $2 \sim 3$ 週に手術を行うのがよいと考え ている.

眼窩底骨折部へのアプローチには下眼瞼経由 法と上顎洞経由法，およびそれらの合併法の 3 つがある。下眼瞼経由法では, 眼窩底骨折部を 直視下におくことができ, 骨折の程度, 眼窩内 容嵌入の程度を確認できるし，骨片などを骨欠 損部に移植するのにも好都合である，また，わ れわれの述べた 2 症例のように，眼窩縁の骨折 部を鋼線で骨間結禁固定する場合には，乙の方 法は必須である。下眼瞼経由法では皮切による 顔面の瘢痕の残存が欠点とされているが，入念 な縫合，適切な創処置を行えばての問題は解決 できると考える. 今回報告したわれわれの 2 症 例でも, 術後 $1 \sim 2$ 力月で皮膚切開線はほとん ど消失し, 注意深い観察でやや認める程度のも のしか残存しなかった。 また，われわれの経験 では大部分の例で上顎洞経由法の併用を必要と していない.

眼窩底部の骨壁は薄く，乙の部の骨折では大 部分の例で骨欠損を生じている，従って，欠損 部の補填が必要となる．補填材料としては腸 骨, 肋軟骨, 上顎洞前壁などの自家骨片4)819)や シリコン, テフロンなどの alloplastic impla$\mathrm{nt}^{10)}$ が用いられている. シリコン板などの alloplastic implant は, 適当な大きさや形に トリミングして用いうる利点があるが, 自家骨 
移植に比べて異物反応を惹起し感染を起こす危 険が少くない．Emery ${ }^{17)}$ はこのような症例を あげ，挿入したプレートが突出して除去を余儀 なくされたと報告している，腸骨採取は新たな 部位に術創を作らねばならない不備がある。上 顎洞前壁骨片の採取は, 上顎洞経由法, 下眼瞼 経由法のいずれでも行うことができるが，眼窩 底骨欠損部の大きさ，形によっては，それに適 合するものを得ることが比較的困難である．ま た，われわれの症例のように，前壁に粉砕骨折 がおこり適当な骨片採取の困難な例も少くな い.とれらの不備を補うため，われわれは上顎 洞に陥入している骨折片を採取し，鋼線または ナイロン糸で接合して適当な大きさの一枚の骨 片とし，乙れを眼窩底骨欠損部に補填する方法 を考案した。この際，第 1 例では骨片の接合に 鋼線を使用し，第 2 例ではナイロン系を使用し た. その結果, 鋼線に比べナイロン系の方が扱 いやすく, 接合が容易であり, また, 強度む十 分であることがわかった，補填した骨片は眼窩 下縁に穿った小孔にナイロン系を通して固定し 移動を防いだ。

眼窩底骨折部の支持, 固定には上顎洞にガー ゼタンポンを充填する方法があり, それが上顎 洞経由法の利点の一つとされている．われわれ は, これにかわる方法として, 従来より, バル ーンカテーテルを使用する方法を行っている. この方法では鼻内より下鼻道側壁に対孔を造設 し，それを介して上顎洞内へバルーンカテーテ
ル（14号程度のものが適当である））を挿入す る. 対孔の造設は，スタッケ一氏溝状ノミとそ の反対側溝状ノミ（松井製）を用いると円形に 開空出来て便利である. バルーンを膨張させ上 顎洞を充填するには生理的食塩水をバルーン中 に注入するとよい. この方法を行うことにより 眼窩底骨折部および移植骨片は十分に支持, 固 定され，また出血屯防止しうる。バルーンカテ 一テルの抜去は術後 7 日から10日で行う. 抜去 には注入した生理的食塩水を除去し, バルーン を縮小させて行うが, 操作は容易であり, 患者 にほとんど苦痛を与えない。なお, 前述の, 上 顎洞に陥入している骨片を採取する際, あらか じめバルーンカテーテルを上顎洞内に挿入し， それを膨ませると洞内に陥入していた小骨片が 押し出されてくるので, 骨片の採取が容易とな る.

この手術に際して，上顎洞粘膜をどのように 取扱うかが問題となるが, 自験によると十分量 の抗生剂を局所的, 全身的に投与すれば，眼窩 蜂窩織炎などは十分に防止できる。

眼窩縁骨片を伴う眼窩壁骨折は，従来の報告 では交通事故によるものが多いとされていた が，最近はスポーツ外傷によるものが増加して いるように見受けられる. 顔面頸部機能外科医 としてのわれわれ耳鼻咽喉科医がこのような症 例を加療する機会が多くなると考えられるの で，以上の 2 症例での経験を中心に述へ，参考 に供した。

\section{語}

眼窩縁骨折を伴う眼窩壁骨折の 2 症例を経験し, その整復に際して， $2 ， 3$ の工夫を行い良好な 成績を得たので, 若干の文献的考察を加え, その概略を報告した.

1 ）眼窩底骨折部へのアプローチとしては, 下眼瞼経由法が上頜洞経由法に比べて有利である. すなわち骨折部に対する視野が広く保たれるので, 眼窩底に補填物を挿入する場合や, 眼窩縁骨折 を結禁固定する場合には, この方法の有用性が高い.

2 ）十分量の抗生剂を局所的，全身的に投与すれば，上顎洞粘膜は剝離，除去する必要はなく， 粘膜を残しておいても眼窩内容への感染を見ることはない.

3 ）眼窩底の骨欠損部の補填には, 上顎洞前壁・眼窩底などの上顎洞内におちこんだ骨片を適当 に接合したものを用いうる。骨片の接合および眼窩縁への固定にはナイロン系を用いれば便利であ 
る.

4 ）鼻内より造設した下鼻道対孔を介して上顎洞内にバルーンカテーテルを挿入し，乙れを膨張 させて眼窩底骨折部を支持, 固定する方法を行っている．乙の方法はまた，ての部の出血防止にも 役立つ. バルーンカテーテルの抜去は容易で, 患者に対する苦痛も少ない. 対孔をあけるにはスタ ッケー氏溝状ノミおよびその反対側溝状ノミを用いると簡単である。

稿を終えるに臨み, 御指導ならびに御校閲を賜った京都大学医学部耳鼻咽喉科学教室主任桧学教授に深謝致し ます.

本論文の要旨は第11回日耳鼻京都滋賀合同地方部会において発表した。

\section{参考文 献}

1) Smith, B. and Regan, W. F. : Blow-out fracture of the orbit. Am. J. Ophth. $44: 733$, 1957.

2 ) Converse, J.M. et al : Orbital Blowout Fractures : A Ten-Year Survey. Plast. \& Reconstruct. Surg. $39: 20,1967$.

3 ) 田嶋定夫, 他: 眼窩内骨折 (blowout fracture) における諸症状, 手術成績などに関する考察. 形 成外科 $20: 184,1977$.

4) 牧野惟男: 眼窩壁骨折について. 耳喉 $48: 795$, 1976.

5 ) 深道義尚：眼窩壁骨折のX線彰断法. 眼科 12 : 410, 1972.

6 ) Converse : Reconst. Plast. Surg. Ch. 25. Saunders Co. Philadelphia, 1977.
7) Emery, J. M. : Orbital floor fractures. long term follow-up of cases with and without surgical repair. Trans. Am. Acad.Ophthalmol. Otolaryngol. $75: 802 \sim 812,1971$.

8 ）上野聖二, 他 : Blowout Fracture 92 症例. 耳 鼻 $20: 735 \sim 739,1974$.

9）坂爪誠, 他: Blowout fracture の治療経験. 日 耳鼻 $78: 28 \sim 33,1975$.

10）本田弘, 他：Blow-out fracture. 山形県病医誌 $8: 40 \sim 43,1974$.

原稿到着：昭和 54 年 11 月 22 日

別刷請求先：土師知行

T710 倉敷市美和 $1-1-1$

倉敷中央病院耳鼻咽唉科 